\title{
Particle-attached bacteria and heterotrophic plankton associated with the Columbia River estuarine turbidity maxima
}

\author{
Byron C. Crump*, John A. Baross \\ School of Oceanography Box 357940, University of Washington, Seattle, Washington 98195, USA
}

\begin{abstract}
A significant fraction of the particulate organic material entering the Columbia River estuary (USA) is metabolized or altered before it is carried out to the ocean. Estuarine turbidity maxima are part of the particle-trapping mechanism that lengthens the residence time of river-borne organic material in an estuary, increasing that material's availability to estuarine bacteria and the estuarine food web. In May and June, 1992, water samples in and around the Columbia River estuarine turbidity maxima were analyzed to determine rates of bacterial carbon production, and bacterial and putative bacterivore abundances. Salinity, turbidity, and tidal data were used to interpret bacterial activity patterns, and to identify distributions of bacterial predators. Bacterial carbon production, based on the rate of ${ }^{3} \mathrm{H}$-thymidine uptake, correlated with turbidity, and varied from 0.3 to $5.6 \mu \mathrm{g} \mathrm{l}^{-1} \mathrm{~h}^{-1}$. Sharp peaks in bacterial production were found in the estuarine turbidity maxima, and were determined to be due to particle-attached bacteria by measuring bacterial production directly on particles. Variation in bacterial production outside the estuarine turbidity maxima seemed to be related to the tidal cycle, supporting hypotheses on particle cycling in the estuary. Nanoflagellates, small 'oligotrich' ciliates and rotifers were the most numerous grazers in the estuary. Correlation analysis between grazer and bacterial abundances and production suggested that rotifers and small ciliates may be the primary consumers of bacteria outside the estuarine turbidity maxima. Rotifers were enhanced in the estuarine turbidity maxima and therefore may be key consumers of particle-attached bacteria.
\end{abstract}

KEY WORDS: Estuarine turbidity maximum - Bacteria Protozoa Rotifers - Bacterial production Particle-attached bacteria Columbia River

\section{INTRODUCTION}

The turbid regions of many estuaries are composed of resuspended detrital particles or allochthonous material, and may support enhanced bacterial activity. In some systems suspended particles are colonized by bacteria (Goulder 1977, Cammen \& Walker 1982, Painchaud \& Therriault 1989, Potapova \& Korolevskaya 1993) that can contribute significantly to total bacterial activity (Hanson \& Wiebe 1977, Bell \& Albright 1981, Bent \& Goulder 1981, Plummer et al. 1987). However, the role of suspended particle-attached bacteria in estuarine food webs is not well understood. A long-

·E-mail: bcrump@u.washington.edu term goal of our research on the Columbia River estuary is to define this role with respect to bacterial metabolism of allochthonous organic material and to the transfer of bacterial production into the estuarine food web.

The 41182 ha Columbia River estuary, in the northwestern United States, receives a relatively large mean annual river discharge $\left(6700 \mathrm{~m}^{3} \mathrm{~s}^{-1}\right)$ and $7.6 \times$ $10^{9} \mathrm{~kg} \mathrm{yr}^{-1}$ of sediment input (Simenstad et al. 1990). It is a partially mixed estuary characterized by a strong tidal cycle (maximum semidiurnal range $3.6 \mathrm{~m}$ ), high turbidity, and vertical stratification that varies in strength with the tides (Sherwood \& Creager 1990). Its hydrodynamics support estuarine turbidity maxima (ETMs) at the upstream limit of the salinity intrusion 


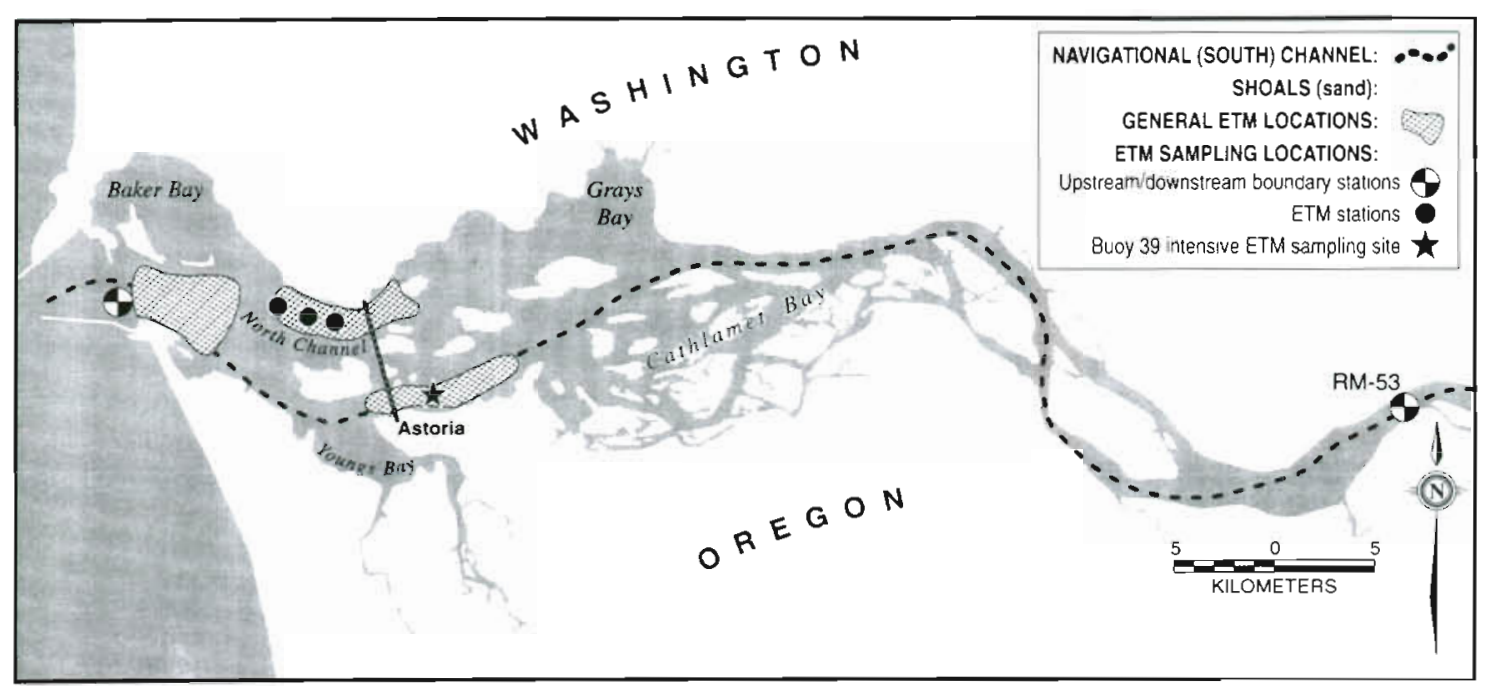

Fig. 1. Columbia River estuary (USA) and location of sampling sites in the South (navigational) Channel at Buoy 39 and in the North Channel, and the extent of the estuarine turbidity maxima

in both of the main (north and south) channels (Fig. 1) (Jay 1994). These ETMs are composed of suspended detrital material that averages $3 \%$ to $10 \%$ organic material by weight (Reed \& Donovan 1994). Particle concentrations can be as high as $1 \mathrm{~g} \mathrm{l}^{-1}$. Much of the particulate organic matter in the ETM probably undergoes some microbial transformation in sub-oxic sediments, and is thought to be washed in periodically from peripheral bays and mudflats during strong flood and ebb tides (Prahl \& Coble 1994). Once in the main channels, this pool of particles cycles between the water column and the surface sediments through settling and resuspension. The ETM environment in the Columbia River estuary can be viewed as a combination of mobile regions of suspended particulate material and the surface sediments with which they exchange particles

Annual particulate organic carbon inputs into the estuary are estimated to be almost entirely detrital particles $(65 \%)$ and river-borne phytoplankton $(27 \%)$ which perish in saline waters, with the remaining $8 \%$ being estuarine phytoplankton production (Small et al. 1990). The predominance of detrital organic carbon implies that a significant amount of the organic carbon consumed in the estuary may pass through a detrital food web of bacteria and other detritivores which may then support higher estuarine trophic levels.

Earlier work found that the Columbia River ETMs support significantly higher bacterial carbon production $(\mathrm{BCP})$ without a comparable increase in bacterial abundance relative to less turbid areas. This was interpreted as evidence supporting an enhanced microbial food web in the ETM. BCP in the estuary far exceeded that required to support the observed proto- zoan population (Baross et al. 1994). However, variability in protozoan and metazoan abundances confounds interpretation of this microbial food web Detritivorous copepods are concentrated in the ETM. and are capable of consuming particle-attached bacteria. Considering that up to $39 \%$ of bacterial activity in the ETM was associated with $>20 \mu \mathrm{m}$ diameter particles, it was concluded that copepods could be effective grazers of bacterial production in the ETM (Morgan 1993, Simenstad et al. 1994b).

This paper seeks to determine the importance of particle-attached bacteria in this system and to explain observed patterns of suspended bacterial activity by analyzing measurements of ${ }^{3} \mathrm{H}$-thymidine uptake, bacterial abundances, and variation in particle concentrations in and around the ETM. It also attempts to identify key consumers of bacterial production in the estuary using abundance estimates of heterotrophic plankton.

\section{MATERIALS AND METHODS}

Sampling focused on the estuarine turbidity maximum (ETM) in the South Channel of the Columbia River estuary at Buoy 39 (Fig. 1) over periods of 8 to $30 \mathrm{~h}$, with one long series of $112 \mathrm{~h}$ during May and June 1992. An ETM passed this site during every sampled flood and ebb tide. The ship remained anchored, and samples were taken every $2 \mathrm{~h}$ in order to follow changes over the tidal cycle (Simenstad et al. 1994a). During one greater flood tide in the North Channel the ship followed the ETM up the estuary and sampled at 3 different times and locations. 
Water samples were collected using a high volume, low pressure pump system coupled with a conductivity-temperature-depth (CTD) meter and an optical backscatter (OBS) sensor for detecting turbidity. The weight of suspended particulate material (SPM) was determined during the $112 \mathrm{~h}$ sampling series by pressure filtering 2 to 41 of sample water onto pre-weighed polycarbonate filters $(90 \mathrm{~mm})$ and correcting the gravimetric particle weight for the salt content using a neutron activation measurement of chloride (Prahl \& Coble 1994) and the assumption of constant salt composition for seawater (OPEN University 1989). For all other samples, SPM was calculated from OBS readings using the empirically derived equation OBS $=0.39$ (SPM 7.5) (Simenstad et al. 1994a).

Bacterial carbon production (BCP) was measured in samples collected near the bottom of the estuary during the last $72 \mathrm{~h}$ of the $112 \mathrm{~h}$ series at Buoy 39 and in samples collected at a range of depths in the water column through ETMs, including the ETM sampled 3 times in the North Channel of the estuary. BCP was calculated from the incorporation rate of tritiated [methyl${ }^{3} \mathrm{H}$ ) thymidine $\left({ }^{3} \mathrm{H}-\mathrm{TdR}\right)$ into bacteria during duplicate $1 \mathrm{~h}$ incubations at ambient temperature (Baross et al. 1994). (Conversion factors: $2 \times 10^{18}$ cells mol TdR ${ }^{-1}, 25 \mathrm{fg}$ carbon cell ${ }^{-1}$; Bell 1993.) Incubations were processed using the Cold TCA extraction technique (Bell 1993). In 8 ETM samples ${ }^{3} \mathrm{H}$-TdR uptake experiments were run using both whole bottom water samples and the $>20 \mu \mathrm{m}$ particle size fraction. Particles were gently captured in a shallow $250 \mathrm{ml}$ plastic tub equipped with an in-port on one side and $20 \mu \mathrm{m}$ nitex screen sealed over the open top (E. Lessard pers. comm.). Water samples slowly entered the in-port and filtrate drained out of the top of the tub. The filtrate was captured, passed through a $0.2 \mu \mathrm{m}$ filter, and used to resuspend the $>20 \mu \mathrm{m}$ particles to the original concentration.

Near-bottom samples collected during the $72 \mathrm{~h}$ sampling series were analyzed for abundances of bacteria, small flagellates, ciliates, and rotifers. The full range of salinity was not represented in this series, so samples from a series collected $2 \mathrm{~d}$ later at the same location were also analyzed. Organisms were fixed with $4{ }^{\circ} \mathrm{C}$ glutaraldehyde ( $2 \%$ final conc.) and stored in the dark at $2^{\circ} \mathrm{C}$. Bacteria and nanoflagellates were filtered onto black $0.2 \mu \mathrm{m}$ filters, stained with DAPI (Sigma) (Porter \& Feig 1980), and counted with a Zeiss UEM microscope. Larger organisms were stained with DAPI and enumerated with a Zeiss Axiovert 35 inverted epifluorescent microscope equipped with a computer-aided digitizing system (Roff \& Hopcroft 1986) for measuring biovolumes. Biomass (in carbon) was calculated from biovolume using the following conversion factors: $0.14 \mathrm{pg} \mu \mathrm{m}^{-3}$ for 'oligotrichs' (Putt \& Stoecker 1989) (also used for other ciliates except tintinnids), $0.053 \mathrm{pg}_{\mathrm{mm}^{-3}}$ for tintinnids (Verity \& Langdon 1984), and $0.19{\mathrm{pg} \mathrm{mm}^{-3}}^{-3}$ for dinoflagellates (E. Lessard pers. comm.).

\section{RESULTS}

\section{ETM-associated bacterial activity}

Peaks in bacterial carbon production (BCP) were associated with almost every peak in suspended particulate material (SPM) during the $72 \mathrm{~h}$ sampling series (Fig. 2),
Fig. 2. (A) Turbidity (solid line, shaded below for clarity) and bacterial production measurements (dashed line) from averaged duplicate experiments on near-bottom samples at Buoy 39 during the last $75 \mathrm{~h}$ of the $112 \mathrm{~h}$ sampling series. Variability in duplicate thymidine uptake experiments averaged $0.7 \mathrm{\mu g} \mathrm{l}^{-1} \mathrm{~h}^{-1}$ for all points except at Hour 82 when the range was $3.6 \mu \mathrm{g} \mathrm{l}^{-1} \mathrm{~h}^{-1}$. The bar between graphs (A) and (B) shows the tidal cycle with black representing flood tides. The natched periods represent stronger ebbs. (B) Salinity variations in near-bottom samples at Buoy 39

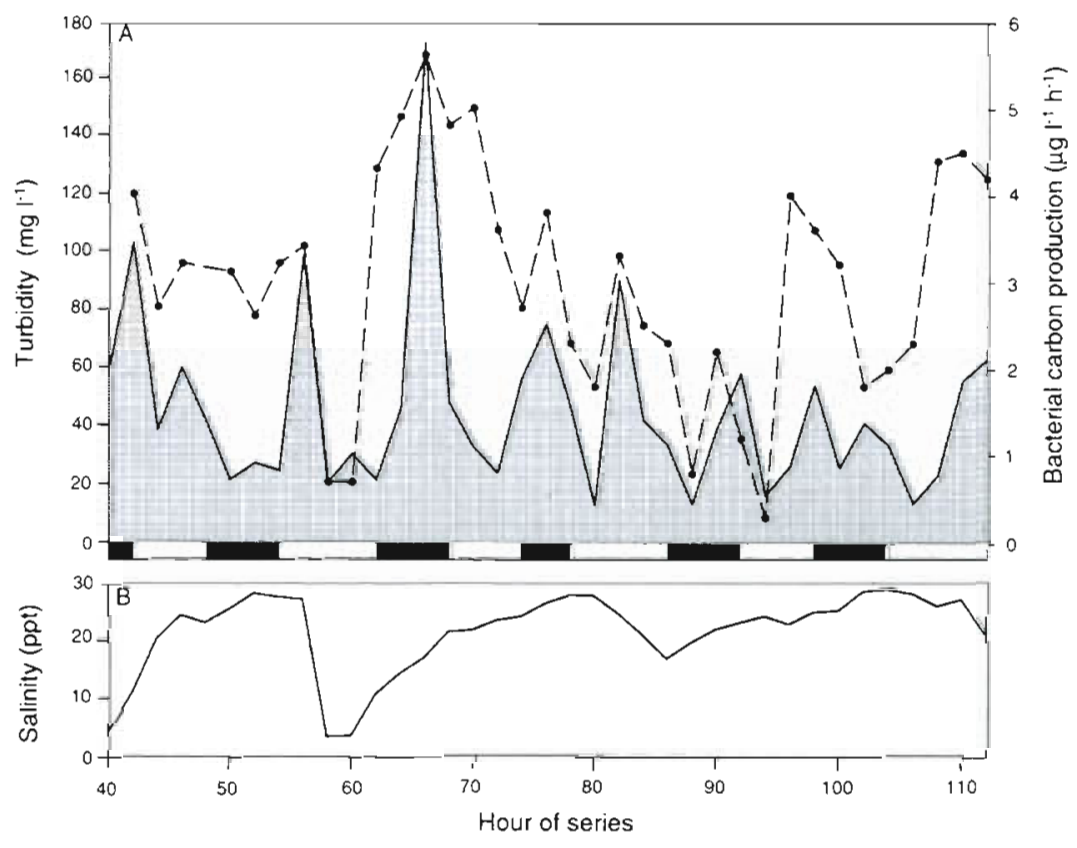



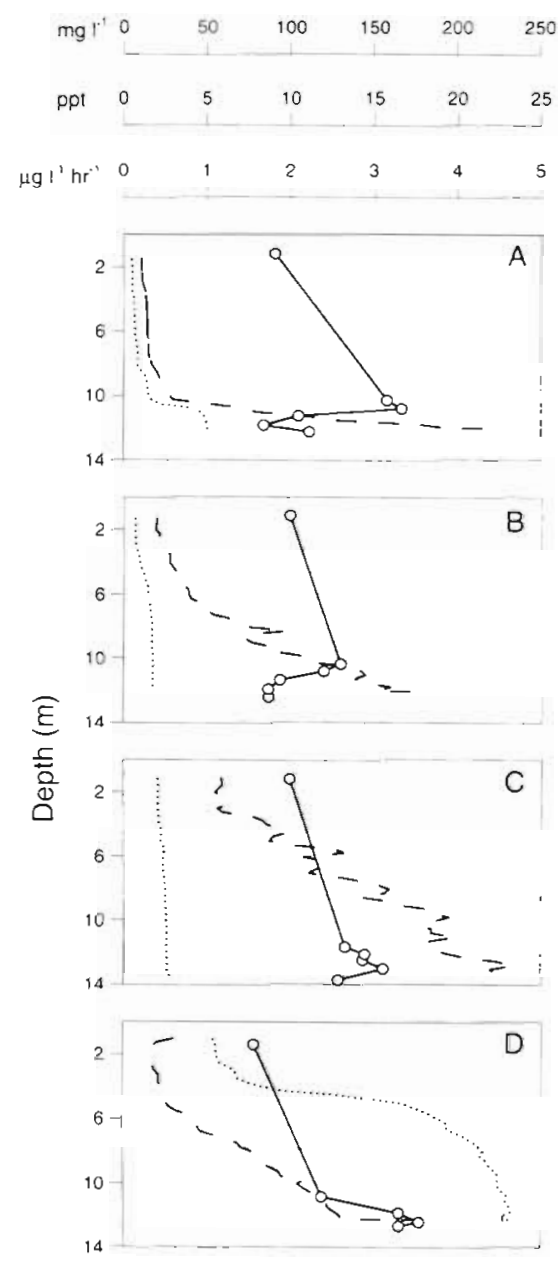

Fig 3. Depth profiles depicting turbidity $\left(\mathrm{mg} \mathrm{l}^{-1}\right.$ suspended particulate material, dashed line), salinity (parts per thousand, dotted line), and bacterial carbon production ( $\mu$ g carbon $\mathrm{I}^{-1} \mathrm{~h}^{-1}$, solid line) (A, B) late during strong flood tides, (C) early during a strong flood, and (D) in the middle of a weak ebb. Variability in bacterial production was the same as in Fig. 2

producing a significant positive correlation between SPM and BCP (see Table 3). However, the pattern was not exact in that some peaks in BCP occurred in less turbid waters just upstream or downstream of the most turbid region of the ETM. The salinity of these bottom samples dropped quickly during 3 strong ebbs starting at Hours 56, 80 and 110. BCP upriver and in 100\% seawater at the mouth of the estuary were always less than $1.0 \mu \mathrm{gl}^{-1} \mathrm{~h}^{-1}$.

Depth profiles of $\mathrm{BCP}$ also demonstrated enhanced microbial activity associated with the ETM (Fig. 3); however, this enhancement was variable within the ETM even at constant salinity. In samples taken near the beginning of the flood (Fig. $3 \mathrm{C}$ ) and during the ebb (Fig. 3D), the highest BCP was associated with the deepest, most turbid samples. However, in samples
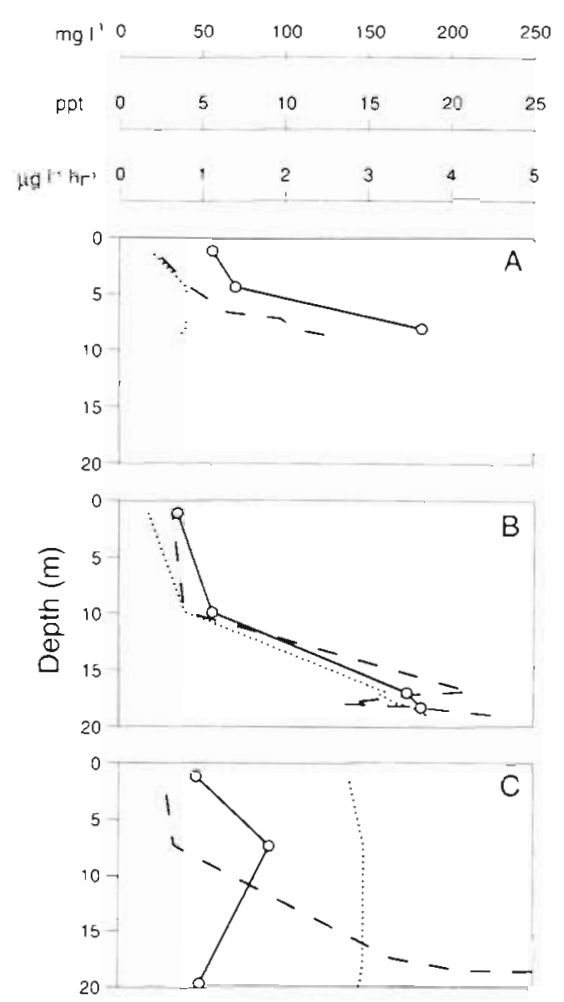

Fig. 4. Depth profiles through an ETM at 3 times and 3 sampling sites depicting turbidity $\left(\mathrm{mg} \mathrm{l}^{-1}\right.$ suspended particulate material, dashed line), salinity (parts per thousand, dotted line), and bacterial carbon production ( $\mu \mathrm{g}$ carbon $\mathrm{H}^{-1} \mathrm{~h}^{-1}$, solid line) during a strong flood tide in the North Channel of the estuary. (A) Early during the strong flood (depth at the sampling site was only $9 \mathrm{~m}),(B)$ in the middle of the strong flood, (C) late during the strong flood. Variability in bacterial production was the same as in Fig. 2

taken late during flood tides (Fig. 3A, B) highest BCP was found near the top of the ETM, 1 to $2 \mathrm{~m}$ off the bottom in relatively less turbid water.

When a flood tide ETM was sampled 3 times as it progressed up estuary it was found that $\mathrm{BCP}$ was initially highest in the turbid bottom sample (Fig. 4A). At the next station the $\mathrm{BCP}$ in the bottom sample remained high as the salinity and turbidity increased (Fig. 4B) At the last station, the BCP in the bottom water decreased even though the turbidity remained high and the salinity did not change (Fig. $4 \mathrm{C}$ ). It is possible that at the last station elevated $\mathrm{BCP}$ occurred at a shallower depth in the ETM as observed in other late flood ETMs (Fig. 3A, B).

\section{Production by particle-attached bacteria}

BCP associated with $>20 \mu \mathrm{m}$ particles in the ETM ranged from 0.4 to $2.0 \mathrm{\mu g} \mathrm{l}^{-1} \mathrm{~h}^{-1}$, or $13 \%$ to $53 \%$ of $\mathrm{BCP}$ measured in unfiltered (whole) water (Table 1). 


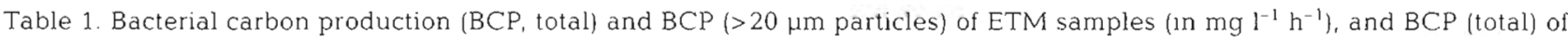
non-ETM samples of similar salinity to ETM samples collected near the same time. The last column shows the difference between the BCP of the whole water ETM and non-ETM samples. Salinity (S, parts per thousand), suspended particulate material (SPM, $\mathrm{mg} \mathrm{l}^{-1}$ ), and the time intervals between the ETM and non-ETM samples are provided for reference

\begin{tabular}{|c|c|c|c|c|c|c|c|c|c|}
\hline \multirow{2}{*}{$\begin{array}{l}\text { Location and } \\
\text { tide stage }\end{array}$} & \multicolumn{4}{|c|}{ ETM samples } & \multicolumn{3}{|c|}{ Non-ETM samples } & \multirow{2}{*}{$\begin{array}{l}\text { Interval } \\
\text { between } \\
\text { samples }\end{array}$} & \multirow{2}{*}{$\begin{array}{c}\text { Difference } \\
\text { between } \\
\text { BCP rates }\end{array}$} \\
\hline & $\mathrm{S}$ & SPM & $\mathrm{BCP}$ & $\begin{array}{c}\mathrm{BCP} \\
\text { (particles) }\end{array}$ & $\mathrm{S}$ & SPM & $\mathrm{BCP}$ & & \\
\hline \multicolumn{10}{|l|}{ Buoy 39} \\
\hline Early neap ebb & 25 & 52 & 1.46 & 0.78 & 21 & 15 & 0.79 & None & 0.67 \\
\hline Mid neap ebb & 25 & 133 & 3.31 & 1.51 & 28 & 14 & 1.79 & $2 \mathrm{~h}$ & 1.52 \\
\hline Late neap ebb & 16 & 122 & 3.08 & 0.39 & 22 & 9 & 1.60 & $3 \mathrm{~h}$ & 1.48 \\
\hline Late spring flood & 2 & 190 & 1.74 & 0.91 & & & & & \\
\hline \multicolumn{10}{|l|}{ North channel } \\
\hline Early spring flood & 2 & 203 & 2.57 & 1.03 & 2 & 37 & 2.00 & None & 0.57 \\
\hline Mid spring flood & 3 & 179 & 2.70 & 0.46 & 2 & 37 & 1.57 & $23 \mathrm{~h}$ & 1.13 \\
\hline Early neap flood & 4 & 124 & 3.64 & 0.50 & 4 & 43 & 1.40 & None & 2.24 \\
\hline Early neap flood & 19 & 224 & 3.64 & 2.02 & 15 & 34 & 1.82 & $1.5 \mathrm{~h}$ & 1.82 \\
\hline
\end{tabular}

BCP in ETM samples was always higher than in nonETM samples collected at about the same time. The difference in BCP between ETM and non-ETM samples (last column of Table 1) was similar to the $\mathrm{BCP}$ of the bacteria associated with the $>20 \mu \mathrm{m}$ size fraction of the ETM samples, showing that particle-attached bacterial activity accounts for most of the enhanced bacterial production observed in these ETMs. The tendency of this difference in BCP to be slightly higher than the $\mathrm{BCP}$ associated with the $>20 \mu \mathrm{m}$ particles may have been due either to particles that passed the $20 \mathrm{\mu m}$ filter or to the small salinity differences and time lags between ETM and nonETM samples

\section{Zooplankton}

Numerically, the dominant ciliates in the estuary were 20-30 $\mathrm{mm}$ long oligotrichs (sensu Lynn \& Corliss 1991). Other protozod identified were Didinium (a raptorial ciliate), $\sim 100 \mu \mathrm{m}$ long heterotrophic dinoflagellates (identification parameters were cell shape, nucleus appearance, and food-filled vacuoles), and a polyphyletic assemblage of prolate spheroid 'holotrichous' species. The 'holotrichs' were divided into groups of large $\left(>120000 \mu^{3}\right)$ and small $\left(<93000 \mu^{3}\right.$ ) cells. Abundances of these organisms were restricted to distinct salinity ranges, and abundances in ETM samples were the same as in non-ETM samples (Fig. 5). The total number of some less abundant protozoa and metazoa counted in each sample were low (Table 2) because of a low sample volume $(20 \mathrm{ml})$.
Rotifers were numerically the most abundant eukaryote counted in this study after the much smaller oligotrichs and flagellates. The rotifer population was
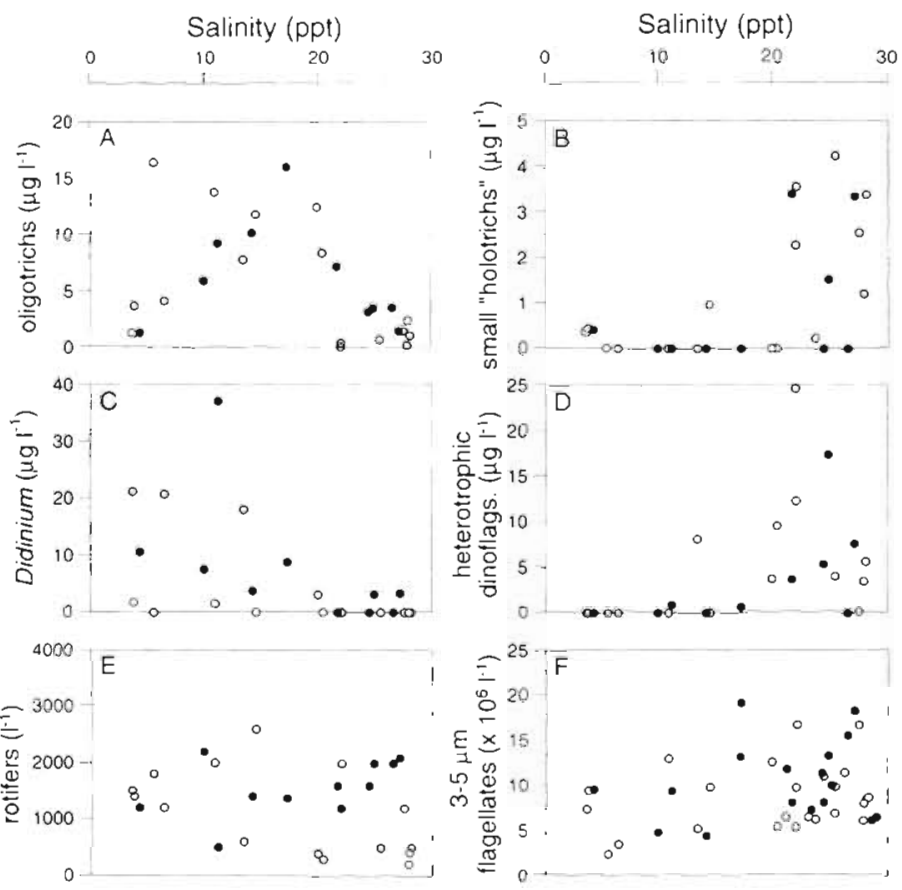

Fig. 5. Abundance estimates of different eukaryotes in the Columbia River estuary presented as biomass or individuals $\mathrm{l}^{-1}$. (A) 20 to $30 \mathrm{~mm}$ long 'oligotrich' ciliates, (B) small 'holotrich'-type ciliates (biovolume $<90000 \mathrm{~mm}^{3}$ ), (C) Didinium ciliates, (D) heterotrophic dinoflagellates, (E) mixed assemblage of rotifers dominated by Keratella sp., (F) microflagellates ( 3 to $5 \mathrm{~mm}$ diameter). (•) Samples from the ETM corresponding to the peaks in turbidity shown in Fig. 2. Rotifer abundance in ETM samples was significantly greater than in non-ETM samples (Mann-Whitney test, $0.05<\mathrm{p}<0.1$ ). For all other plankton types abundances in ETM and non-ETM samples were not significantly different $(0.20<p)$ 
Table 2. Abundance ranges of microscopic organisms in samples from the Columbia River estuary, presented as individuals counted per sample, individuals per liter and biomass per liter for organisms with size variation

\begin{tabular}{|c|c|c|c|}
\hline Plankton types & $\begin{array}{l}\text { Individuals } \\
\text { counted }\end{array}$ & $\begin{array}{l}\text { Abundance } \\
\text { (ind. } 1^{-1} \text { ) }\end{array}$ & $\begin{array}{l}\text { Biomass } \\
\left(\mathrm{mg} \mathrm{Cl}^{-1}\right)\end{array}$ \\
\hline \multicolumn{4}{|c|}{ Most abundant organisms } \\
\hline Bacteria & & $1.2-5.2 \times 10^{9}$ & \\
\hline $2-5 \mu \mathrm{m}$ flagellates & & $5.4-19.2 \times 10^{6}$ & \\
\hline $20-30 \mu \mathrm{m}$ oligotrichs & $0-153$ & $0-19000$ & $0-16.0$ \\
\hline Rotifers (total) & $2-21$ & $300-2600$ & \\
\hline Keratella & $1-18$ & $200-2200$ & \\
\hline Polyartha & $0-5$ & $0-500$ & \\
\hline Kellicotia & $0-5$ & $0-600$ & \\
\hline Other rotifers & $0-3$ & $0-600$ & \\
\hline \multicolumn{4}{|l|}{ Other plankton } \\
\hline Small holotrichs & $0-8$ & $0-800$ & $0-4.3$ \\
\hline Large holotrichs & $0-2$ & $0-200$ & $0-18.6$ \\
\hline Didinium & $0-8$ & $0-800$ & $0-37.2$ \\
\hline Hetero dinoflagellates & s $0-8$ & $0-800$ & $0-24.7$ \\
\hline Tintinnids & $0-11$ & $0-1100$ & $0-3.8$ \\
\hline
\end{tabular}

dominated by a Keratella sp. (Table 2), which was commonly seen carrying eggs. Unlike ciliates, rotifers did not appear to be restricted to any salinity range (Fig. 5). Rotifer abundance was higher in ETM samples than in non-ETM samples (Fig. 5), as demonstrated by the positive correlation between rotifers and turbidity (SPM, Table 3).

Total bacterial numbers varied from $1.2 \times 10^{6}$ to $5.2 \times$ $10^{6} \mathrm{ml}^{-1}$. Small flagellates varied from $5 \times 10^{3}$ to $20 \times$ $10^{3} \mathrm{ml}^{-1}$ and correlated with bacterial numbers (Tables 2 \& 3). Bacteria and flagellates did not correlate with turbidity or $\mathrm{BCP}$ although particle-attached bacteria and flagellates were commonly seen in the samples (Table 3 ).

\section{DISCUSSION}

\section{Bacterial activity and abundance in the ETM}

The conclusion that some turbid regions of the Columbia River estuary supported higher bacterial carbon production (BCP) than low turbidity waters has been reported for other estuaries. In both the Humber and the Severn estuaries (UK), total bacterial heterotrophic activity correlated with suspended solid concentration and with particulate organic carbon (POC) (Bent \& Goulder 1981, Joint \& Pomeroy 1982). Similarly, in the Tamar estuary (UK) a marked increase in total bacterial activity was associated with an increase in turbidity (Plummer et al. 1987), and in the upper Saint Lawrence estuary (Canada) the ETM supported higher total heterotrophic potential (Painchaud \& Therriault 1989). Since particle-attached bacteria in
Table 3. Spearman rank correlation coefficients between abundances of common plankton in the Columbia River estuary and bacterial abundance (Bacteria), bacterial carbon production (BCP), and turbidity (SPM). Coefficients for oligotrich ciliates were calculated with biomass estimates due to the notable variation in size of these organisms, and only for counts from samples with salinities ranging from 1 to $22 \mathrm{ppt}$, which was their apparent range. Significant correlations $(0.01<p<0.05)$ are presented in bold type. $n$ is the number of pairwise comparisons

\begin{tabular}{|c|c|c|c|c|c|}
\hline & Bacteria $n$ & $S P M$ & $\mathrm{n}$ & $\mathrm{BCP}$ & $\mathrm{n}$ \\
\hline SPM & & & & 0.413 & 36 \\
\hline Bactena & & 0.215 & 42 & 0.199 & 35 \\
\hline $2-5 \mu \mathrm{m}$ flagellates & $0.384 \quad 41$ & 0.106 & 41 & 0.101 & 35 \\
\hline $20-30 \mu \mathrm{m}$ oligotrichs & $0.261 \quad 15$ & 0.057 & 15 & 0.612 & 10 \\
\hline Rotifers (total) & 0.56126 & 0.410 & 26 & 0.512 & 20 \\
\hline
\end{tabular}

coastal and estuarine environments have been found to be more active on a per-cell basis than free-living cells (Hodson et al. 1981, Iriberri et al. 1987, Unanue et al. 1992, Griffith et al. 1994), it can be inferred that, when present, they are responsible for peaks in bacterial activity associated with turbid regions of estuaries. This inference is also applicable to the Columbia River estuary where particle-attached bacteria composed up to $50 \%$ of the total bacteria in the ETM. In addition, ETM particle-attached bacteria appeared larger than most free-living cells, suggesting that they were more active (Hodson et al. 1981, Iriberri et al. 1987). We confirmed this by measuring bacterial production directly on particles collected from the ETM and noting that the scale of the enhancement in BCP associated with the ETM was the same as the BCP associated with the particles. The same result can be drawn from similar research on other estuaries (Hanson \& Wiebe 1977, Bell \& Albright 1981, Bent \& Goulder 1981, Plummer et al. 1987)

\section{ETM particles vary in organic content and composition}

The weak correlation between BCP and turbidity $(0.01<\mathrm{p}<0.02)$ (Table 3) and the variation in BCP in the ETM at different depths and times (Figs. 2, $3 \& 4$ ) suggest that not all ETM particles support bacterial activity. The particles that make up an ETM could vary in 2 relevant ways: the total organic content of the particles and the composition of the organic material. Reed \& Donovan (1994) showed that the organic content of the suspended particles in the Columbia River estuary is considerably different between a flood and an ebb tide, probably due to the greater resuspension of sand grains or other inorganic particles during ebb 
tides. The composition of particulate organic material could also change as it is used by bacteria and other grazers, becoming less labile and supporting a less productive complement of bacteria.

The abundance and type of particles in the ETM depend on a complicated system of particle cycling between the water column and the sediments. Changes in the velocity of water over the sediment lead to variability in the size and amount of particles resuspended into the ETM. Also, changes in water velocity and shear stress levels in the water column lead to variability in the degree of aggregation of particles in the ETM and therefore their sedimentation rate (Reed \& Donovan 1994, Reed pers. comm.). The results presented in this paper show that ETMs in this system are heterogeneous both spatially and temporally (Figs. 3 \& 4), so although regions of enhanced $\mathrm{BCP}$ are generally associated with the ETM, every part of an ETM does not support enhanced BCP.

\section{Patterns in bacterial activity outside the ETM}

The conclusion that particle-attached bacteria accounted for increased BCP in ETMs was confounded by the observation that bacterial production in the ETM was at times lower than production outside the ETM. For example, in Fig. 2, BCP at Hour 72 in a non-ETM sample was higher than the BCP in the ETM sample at Hour 90. Water sampled between ETM events represented 'background' BCP which probably changed over the tidal cycle. Background BCP could have resulted from growth of free-living bacteria or from bacteria associated with particles so small that they did not produce a significant optical backscatter signal.

Particle-attached bacterial activity associated with the ETM of the Tamar River estuary was highest on 'permanently suspended particles' (PSPs), or particles that did not settle out after $12 \mathrm{~h}$ in a settling chamber (Plummer et al. 1987). PSPs in the Tamar did not contribute much to the turbidity in the ETM, but were responsible for the lower levels of turbidity measured outside the ETM. These investigators also found that PSPs were concentrated in the ETM along with the settling fraction. Although the Tamar is considerably smaller than the Columbia, the 2 systems are similar in that both are partially mixed estuaries with similar flushing times that support mobile ETMs and are flanked by tidal mudflats. The concentration of PSPs in the Tamar ETM may be due to aggregation with sinking particles by mechanisms similar to those in the Columbia River estuary. Bacteria attached to PSPS originating from the mudflats and disaggregating from particles in the ETM could enhance total BCP in non-
ETM regions of the Columbia River estuary water column without affecting the overall turbidity. Bacteria attached to PSPS could also provide a mechanism for the variability in vertical profiles of $B C P$ through the ETM as well as in background levels of BCP. Bacteria attached to small particles were seen in non-ETM samples from the Columbia River estuary, however their carbon production rate separate from free-living cells was not quantified. The source of BCP in non-turbid regions of the Columbia River estuary is a subject of ongoing research.

Background BCP measurements, or BCP in nonETM samples (Fig 2), did not correlate with salinity, turbidity, or any parameter measured in this study except perhaps with the tidal cycle. After each strong ebb in the series (ending at Hours 34, 61 and 85), there was a sharp increase in background BCP which decreased over time until the next strong ebb. This can be explained by the particle cycling hypothesis developed for the Columbia River estuary (C. A. Simenstad et al. unpubl.) which suggests that during the strong ebb new POC, dissolved organic carbon, and bacterial cells enter the estuary and older particles disaggregate from particles in the ETM. Both of these inputs would enhance $\mathrm{BCP}$ in non-ETM regions of the estuary. During the flood and weak ebb tides that follow, excess $\mathrm{BCP}$ is concentrated in the ETM and carried to the bottom of the main channel by aggregation with sinking particles (Reed \& Donovan 1994). This phenomenon is demonstrated by the observation that, while background levels of BCP decreased after a strong ebb, peaks associated with the ETM became progressively stronger (Fig. 2).

\section{Detrital food web}

Potential pelagic and epibenthic bacterivores were diverse in the estuary. The dominant species included rotifers, small oligotrichous ciliates, and nanoflagellates. Due to the abundance of particle-attached bacteria, bacterial carbon in the estuary is packaged in many particle sizes and may be available as food to all these grazers. One study suggested that copepods in the Columbia River estuary consume particle-attached bacteria (Simenstad et al. 1994b). Bacteria may be consumed at many different trophic levels in the plankton, complicating and 'short-circuiting' the microbial loop (Baross et al. 1994). Correlations between abundances of the dominant grazers and the different bacterial measurements provide some clues to the structure of the detrital food web.

Ciliates are capable of rapid growth in response to an increase in their food source (Fenchel 1980), so it is reasonable to see a weak correlation between olig- 
otrichs and $\mathrm{BCP}(0.05<\mathrm{p}<0.1)$ (Table 3$)$. However, despite this correlation, oligotrich biomass did not correlate with turbidity (Table 3, Fig 5). These organisms may be too small to be trapped like ETM particles, but this does not explain why they do not respond to the increased bacterial carbon production of the ETM (Fig. 5A). It may be that these organisms cannot graze on particle-attached bacteria, or that oligotrich abundance is kept low by the grazers whose abundances do track turbidity, such as rotifers and copepods.

Rotifer abundances were similar to those reported in other estuaries where rotifers dominated the mesozooplankton population (Konnur \& Azariah 1987, Heinbokel et al. 1988, Dolan \& Gallegos 1991). Rotifer abundance correlated with SPM and bacterial abundance (Table 3), suggesting that they were concentrated in the ETM, perhaps by the same mechanism that traps detrital particles. This would help rotifers maintain their levels in the estuary, and, being that rotifers are capable of consuming many types of food including detrital particles (Bogdan et al. 1980, Starkweather 1980), would also help them maintain proximity to a major food source, particle-attached bacteria. A similar strategy has been hypothesized for copepods in the estuary, which suggests a combination of passive (particle-like) retention and active swimming as mechanisms for maintaining different estuarine copepod populations (Morgan 1993, Simenstad et al. 1994b). Rotifer abundance also correlated with BCP, suggesting that they may be feeding on bacteria in non-ETM waters.

\section{CONCLUSIONS}

At least 2 factors control levels of bacterial production in the water column of the Columbia River estuary. The first is bacteria associated with $>20 \mu \mathrm{m}$ particles, which contributed significantly to the total bacterial production in and around the ETM. This factor varied on a spatial scale, probably due to variability in the organic content and composition of particles in different parts of the ETM. The other factor is related to the temporal variability of tidal cycles which appeared to affect the 'background' production of bacteria. Research results in the Tamar River estuary, a system similar to the Columbia, suggest that background levels of $\mathrm{BCP}$ are controlled by particulate organic material and bacteria attached to very small particles that do not contribute much to the turbidity of the water column (Plummer et al. 1987). The concentration of very small bacterially active particles in different parts of the ETM region may explain why levels of total bacterial production did not always match levels of turbidity.
Acknowledgements. Thus research was supported by NSF LMER grant OCE-8907118. We thank the captain and crew of the RV 'Robert Gordon Sproul' and our colleagues on the Columbia River ETM project for all their assistance in the field, C. A. Simenstad for his efforts as chief scientist, F. G. Prahl for the $72 \mathrm{~h}$ series turbidity data, D. J. S. Montagnes, C. A. Simenstad and $K$. Banse for their helpful comments during manuscript preparation, and E. J. Lessard and D. J. S. Montagnes for advice on protozoan and rotifer identification and enumeration, and for the use of the inverted microscope.

\section{LITERATURE CITED}

Baross JA, Crump B. Simeristad CA (1994) Elevated 'microbial loop' activities in the Columbia River estuarine turbidity maximum. In: Dyer KR, Orth BJ (eds) Changes in fluxes in estuaries: implications from science to management (ECSA22/ERF symposium, Plymouth, September 1992\}. Olsen \& Olsen, Fredensborg, p 459-464

Bell CR, Albnght LJ (1981) Attached and free-floating bacteria in the Fraser River Estuary, British Columbia, Canada. Mar Eco! Prog Ser 6.317-327

Bell RT (1993) Estimating production of heterotrophic bacterioplankton via incorporation of tritiated thymidine. In: Kemp PF, Sherr BF, Sherr EB, Cole JJ (eds) Handbook of methods in aquatic microbial ecology. Lewis Publishers, Boca Raton, p 495-503

Bent EJ, Goulder R (1981) Planktonic bacteria in the Humber Estuary; seasonal variation in population density and heterotrophic activity. Mar Biol 62:35-45

Bogdan KG, Gilbert JJ, Starkweather PL (1980) In situ clearance rates of planktonic rotifers. Hydrobiologia 73 . $73-77$

Cammen LM, Walker JA (1982) Distribution and activity of attached and free-living suspended bacteria in the Bay of Fundy. Can J Fish Aquat Sci 39:1655-1663

Dolan JR, Gallegos CL (1991) Trophic coupling of rotifers, microflagellates, and bacteria during fall months in the Rhode River estuary. Mar Ecol Prog Ser 77:147-156

Fenchel T (1980) Suspension feeding in ciliated protozoa: feeding rates and their ecological significance. Microb Ecol 6:13-25

Goulder R (1977) Attached and free bacteria in an estuary with abundant suspended solids. J Appl Bacteriol 43: $399-405$

Griffith P, Shah FK, Gloersen K, Ducklow HW, Fletcher M (1.994) Activity and distribution of attached bacteria in Chesapeake Bay. Mar Ecol Prog Ser 108:1-10

Hanson RB, Wiebe WJ (1977) Heterotrophic activity associated with particulate size fractions in a Spartina alterniflora salt-marsh estuary, Sapelo Island, Georgia, USA, and the continental shelf waters. Mar Biol 42:321-330

Heinbokel JF, Coats DW, Henderson KW, Tyler MA (1988) Reproduction rates and secondary production of three species of the rotifer genus Synchaeta in the estuarine Potomic River. J Plankton Res 10:659-674

Hodson RE, Maccubbin AE, Pomeroy LR (1981) Dissolved adenosine triphosphate utılization by free-living and attached bacterioplankton. Mar Biol 64:43-51

Iriberri J, Unanue M, Barcina I, Egea L (1987) Seasonal variation in population density and heterotrophic activity of attached and free living bacteria in coastal waters. Appl Environ Microbiol 53(10):2308-2314

Jay DA (1994) Residence time, box models and shear fluxes in tidal channel flows. In: Dyer KR, Orth $\mathrm{BJ}$ (eds) Changes in fluxes in estuaries: implications from science to manage- 
ment (ECSA22/ERF symposium, Plymouth, September 1992). Olsen \& Olsen, Fredensborg, p 3-12

Joint IR, Pomeroy AJ (1982) Aspects of microbial heterotrophic production in a highly turbid estuary. J Exp Mar Biol Ecol 58:33-46

Konnur R, Azariah J (1987) Distribution of rotifer biomass in the estuarine region of River Adyar with reference to suspended particulate matter. J Mar Biol Ass India 29:286-290

Lynn DH, Corliss JO (1991) Ciliophora. In: Harrison FW (ed) Microscopic anatomy of invertebrates, Vol 1 Wiley-Liss, New York, p 333-467

Morgan CA (1993) Sink or swim? Copepod population maintenance in the Columbia River estuarine turbiduty maxima region. MSc thesis, Fisheries Research Institute, University of Washington, Seattle

OPEN University (1989) Seawater: its composition, properties and behaviour. Pergamon Press, New York

Painchaud J, Therriault JC (1989) Relationships between bacteria, phytoplankton and particulate organic carbon in the Upper St. Lawrence Estuary. Mar Ecol Prog Ser 56: 301-311

Plummer DH, Owens NJP, Herbert RA (1987) Bacteria-particle interactions in turbid estuarine environments. Cont Shelf Res $7(11 / 12): 1429-1433$

Porter KG, Feig YS (1980) The use of DAPI for identifying and counting aquatic microflora. Limnol Oceanogr 25:943-948

Potapova NA, Korolevskaya TV (1993) Aggregated bacteria in the bacterioplankton of the Dniester River and its estuary. Hydrobiol J 29(7):51-57

Prahl FG, Coble PG (1994) Input and behavior of dissolved organic carbon in the Columbia River estuary. In: Dyer KR, Orth BJ (eds) Changes in fluxes in estuaries: implications from science to management (ECSA22/ERF symposium, Plymouth, September 1992). Olsen \& Olsen, Fredensborg, p $451-457$

Putt M, Stoecker DK (1989) An experimentally determined carbon:volume ratio for marine 'oligotrichous' ciliates from estuarine and coastal waters. Limnol Oceanogr 34: $1097-1103$

Reed DJ, Donovan J (1994) The character and composition of the Columbia River estuarine turbidity maximum. In: Dyer

This article was presented by C. Levings (Senior Editorial Advisor), Vancouver, British Columbia, Canada
KR, Orth BJ (eds) Changes in fluxes in estuaries: implications from science to management (ECSA22/ERF symposium, Plymouth, September 1992). Olsen \& Olsen, Fredensborg $\mathrm{p} 445-450$

Roff JC, Hopcroft RR (1986) High precision microcomputer based measuring system for ecological research. Can J Fish Aquat Sci 43:2044-2048

Sherwood CR, Creager JS (1990) Sedimentary geology of the Columbia River estuary. Prog Oceanogr 25:15-79

Simenstad CA, Morgan CA, Cordell JR, Baross JA (1994b) Flux, passive retention, and active residence of zooplankton in Columbia River estuarne turbidity maxima. In Dyer KR, Orth BJ (eds) Changes in fluxes in estuaries implications from science to management (ECSA22/ERF symposium, Plymouth, September 1992). Olsen \& Olsen. Fredensborg, $\mathrm{p}$ 473-482

Simenstad CA, Reed DJ, Jay DA, Baross JA, Prahl FG, Small LF (1994a) Land-margin ecosystem research in the Columbia River estuary: investigations of the couplings between physical and ecological processes within estuarine turbidity maxima. In: Dyer KR, Orth BJ (eds) Changes in fluxes in estuaries: implications from science to management (ECSA.22/ERF symposium, Plymouth, September 1992). Olsen \& Olsen, Fredensborg, p 437-444

Simenstad CA, Small LF, McIntire CD, Jay DA, Sherwood C (1990) Columbia River estuary studies: an introduction to the estuary, a brief history, and prior studies. Prog Oceanogr 25:1-13

Small LF, McIntire CD, Macdonald KB, Lara-Lara JR, Frey BR, Amspoker MC, Wenfield T (1990) Primary production, plant and detrital biomass, and particle transport in the Columbia River estuary. Prog Oceanogr 25:175-210

Starkweather PL (1980) Aspects of the feeding behavior and trophic ecology of suspension-feeding rotifers. Hydrobiologia 73:63-72

Unanue M, Ayo B، Azúa I, Barcina I, Iriberri J (1992) Temporal variability of attached and free-living bacteria in coastal waters. Microb Ecol 23:27-39

Verity PG, Langdon C (1984) Relationships between lorica volume, carbon, nitrogen and ATP content of tintinnids in Narragansett Bay. J Plankton Res 6:859-868

Manuscript first received: September 1, 1995

Revised version accepted: March 5, 1996 